Bagus Candra Ramadhan; Moses Glorino Rumambo Pandin

Faculty of Humanities, Airlangga University

Campus B, Jl. Dharmawangsa Dalam, Airlangga, Kec. Gubeng, Surabaya, East Java 60286

Email: bagus.can.ramadhan-2020@fib.unair.ac.id; moses.glorino@ fib.unair.ac.id

\title{
Book Title: SEJARAH KERETA API YOGYAKARTA 1917-1942 (HISTORY OF YOGYAKARTA RAILWAYS 1917-1942)
}

\section{Author: Nanang Setiawan; Publisher City: Temanggung; ISBN Number: 978-602-51-3037- 3; Number of Pages: 135 Page}

\section{INTRODUCTION}

The Book Sejarah Kereta Api Yogyakarta 1917-1942 was published as a complement to reading about the railroad network that had existed in the kingdom during the colonial period. In addition, this book is a means of education for the public that trains are not just transportation for mobility from one place to another. However, trains can be a vital element and influence the social, economic, political and cultural conditions in a society. The author also hopes that today's society will not forget about the great contribution that the railroad network has made.

Sejarah Kereta Api Yogyakarta 1917-1942 is a book that can be read and also observed by the general public from various circles. This is even more so for people who live in the Vorstenlanden area or the Yogyakarta Special Region now. For students, this book can be used as a reference or to find a new understanding of the social, community and economic conditions in Yogyakarta during the colonial period. Many children are in junior high or high school and the equivalent who are curious about how trains were in the past.

Next, the author told of how the mobility, social interaction, and economic activities of the Dutch East Indies, especially Yogyakarta and its surroundings, were presented during the colonial period. In addition, it also presents the history of the construction of the Railway network in Yogyakarta and how it affects after it is built. Trains exist as a very reliable and influential means of transportation. By using the train, transporting crops and other export commodities will be faster 
and smoother. The dynamics of further railroad development will be more enjoyable when observing social actions and population growth. The population is increasing, then more and more will also use rail as the main means of mobility for their socio-economic activities.

I choose this as a book to be reviewed because the theme is suitable and in accordance with my hobby, namely trains. Then, this book contains the history of how the condition of society in ancient times before the existence of railroad transportation, the development of railroad development which is increasingly complex, and also what are the influences on society in various fields after the existence of rail transportation. Therefore, the book needs to be reviewed to provide an overview for someone who wants to read about what will be discussed in detail in the book.

\section{RESULTS}

According to the title, in the book, will describe the history of railway development and development in the Vorstenlanden region or the Special Region of Yogyakarta today. It is not only the development and development but also the community's social conditions before the existence of rail transportation and after the construction of the railway network, which will have a big influence. After finishing with all the aspects discussed, the authors provide conclusions that cover the entire contents of book. This, of course, becomes something that makes it easier and is expected by the readers, so that the readers' needs for reading about the history of railways and the social conditions of the people in the Yogyakarta area are fulfilled.

The information presented in the book can satisfy the reader, because it does not only discuss the history of the development of the railway network in the Yogyakarta area, but also various things that influenced it, such as, the background of why it was necessary to build a railway network, what were the colonial interests. To do this, how was the railway line development process carried out by the colonial government, the condition of the area and natural potential, the socio-economic conditions of the community, especially the Yogyakarta area, and the demographic conditions. The railway facilities are also not forgotten to be discussed.

Readers who have read this book, of course, will get a new understanding and point of view about the mode of rail transportation and its long history that accompanies it, from the 
beginning of the construction of the railroad network in the Dutch East Indies to the modern era of railways in Indonesia today.

Effects after reading, the readers will get a new understanding and know that the train is not just a mode of transportation that is only used for mobility, but there is a long history behind it. The train became an amazing technological invention at that time. The train played a vital role in transporting plantation products in the colonial era, then it grew and became the prima donna of the community as a mode of transportation for traveling.

Accurate and fact-based concrete evidence has been presented in the book. Of course, because this book contains history, history is the study of the past through traces or concrete and reliable evidence. The evidence presented by the author, for example, is how the state of the region, the natural and socio-economic conditions of the people in Regentschap Bantul, Kotagede and around Yogyakarta in the colonial era before the construction of the railway line was carried out. All explanations regarding this can be read on pages 9 to 34. The development of railway lines in the region results from Western ambitions represented by the colonial government and private foreign entrepreneurs who also want to exploit tropical products.

The evidence presented is valid and concrete evidence, this is because the author used historical sources that are relevant to the themes discussed. The historical sources used by the author come from institutions that are already well-known, such as, the National Archives of the Republic of Indonesia (ANRI), the National Library of the Republic of Indonesia, the Gajah Mada University Central Library, the Kotagede Heritage Library, the KITLV Digital Library, and many others.

Other evidence that can be observed in the book, in chapter 1 pages 9-26, contains a discussion of the socio-economic conditions of the Bantul and Kotagede regentschap. In the colonial era, to be precise after the initiation of ethical politics, the plantation lands that were previously scattered became one large plantation area. This facilitates the management of land, irrigation, labor, and transportation. Commodities produced from the agricultural and plantation sectors in the Bantul area are increasingly selling well in the market, an example of this commodity is sugarcane. On page 25, there is a table regarding the number of sugar factories in Yogyakarta in 1915-1928. This table is from the Colonial Verslag, 1916, 1922, 1926, 1929. 
Then in chapter 3 starting from page 39, it begins to discuss how the process of building a rail network which definitely deals with the land belonging to the Sultanate. Then it was continued with a discussion regarding the procurement of railroad facilities and infrastructure used and also the development of the rail network to areas outside the city center of Yogyakarta such as Sewugalur and Pundong.

In chapter 4, starting from page 75 , we will discuss what influences impact the social, economic, cultural, and population mobility, and even the opening of job opportunities after the existence of the railway line in Yogyakarta its surroundings. Page 87 describes the influence on the economic aspects of the railroad. Indigenous people get the opportunity to work as NISM employees, besides that the loading and unloading activities at the station also become a place for natives to work as casual laborers. The availability of jobs has finally increased the interest of people from remote areas to come to Kotagede to earn more income.

The writing style of the book is very easy to understand even for someone who is unfamiliar with railways. At the beginning of the book there is a glossary containing various words that the author considers unfamiliar to give to ordinary people. This book consists of 135 pages and is divided into 5 chapters. On each topic discussed, a footnote is always given to make it easier for readers if they want to find references used in the topic being discussed. With only 135 pages and simple chapter divisions, this book still has an interesting substance and can also increase the interest of the general public to read or study history, especially trains.

Then, there are studies or ideas that are slightly ignored by the author and can be reconsidered by the reader, namely regarding the political aspects between the colonial government and the Yogyakarta Sultanate which certainly played an important role in various things that influenced the process of building the railroad network. This political aspect is not discussed too deeply in this book, but only to explain and provide an understanding of the process flow of building a railway network in Yogyakarta. This will be considered again by the reader if a reader wants to know more about how political policies are carried out in order to generate ideas and agreements so that a railway network can be built in the Yogyakarta area and its surroundings.

Some of the advantages that exist are, first is about the style of writing which is very easy to understand even by ordinary people. Second, the explanation of each topic is written coherently 
and is also supported by a footnote that can make it easier for readers to find references related to the topic being discussed. Third, there is a list of terms that contains meanings of unfamiliar terms to ordinary people used in this book and a list of abbreviations containing abbreviations of frequently written abbreviations. Of course, this is very useful for readers so that they do not get confused if they come across foreign words or terms that are often used in the book. Then the fourth, the author also attaches various tables and photos that are relevant to the topic discussed. The various tables and photos that are tied will strengthen the study or facts from the themes discussed in the book.

Apart from the many advantages, there are also some weaknesses. This weakness was the lack of depth or rather neglect of the political aspects that occurred within the Colonial Government and the Yogyakarta Sultanate during the period of forced cultivation to the turmoil that occurred in the Dutch East Indies finally ethical politics was sparked. The political aspects in this book are explained only to provide an understanding of the flow of the railway network development process in the Yogyakarta and surrounding areas.

Overall, this is a good book for people who have a deeper interest in and curiosity about trains and their long history as a mode of transportation that played an important role in various areas of community life in the Yogyakarta area and its surroundings in ancient times. Then, a little suggestion from me to the author is that it is better to make a new section specifically to discuss political dynamics, which have a major influence on the development and development of the railroad network. This is so as not to confuse the reader if political matters appear in sub-chapters that discuss other aspects.

\section{REFERENCES}

1. Setiawan, Nanang. Sejarah Kereta Api Yogyakarta 1917-1942. First. Temanggung: Publisher Kendi; 2020. 135 p

Bagus Candra Ramadhan; Moses Glorino Rumambo Pandin

Airlangga University 


\section{AUTHOR SHORT-BIODATA}

Nanang Setiawan is a man who was born on June 14, 1995 in Yogyakarta. He is a graduate of Yogyakarta State University, the History Study Program. He has more concern and interest in the world of railways. This was finally poured into his thesis entitled "The Socio-Economic Impact of the Yogyakarta - Pundong Railroad Transportation on the Kotagede Community in 1917-1942". Currently, he is continuing his postgraduate education at Gajah Mada University, Faculty of Humanities, History Study Program. 